\title{
Effect of Phaleria Macrocarpa Flesh Fruits Extract on MDA Level, SGOT and SGPT Activity in Serum of Experimental Rats Contaminated by $\mathrm{Cd}$ (II) Ion
}

\author{
Ali Napiah Nasution ${ }^{1,2^{*}}$, Hermansyah Aziz ${ }^{3}$, Djong Hon Tjong ${ }^{4}$, Rahmiana Zein $^{3,5}$
}

${ }^{1}$ Faculty of Mathematics and Natural Sciences, Andalas University, Padang, Indonesia; ${ }^{2}$ Department of Tropical Medicine, Faculty of Medicine, University of Prima Indonesia, Medan, Indonesia; ${ }^{3}$ Department of Chemistry, Faculty of Mathematics and Natural Sciences, Andalas University, Padang, Indonesia; ${ }^{4}$ Department of Biology, Faculty of Mathematics and Natural Science, Andalas University, Padang, Indonesia; ${ }^{5}$ Department of Environmental Analytical Chemistry, Faculty of Mathematics and Natural Sciences, Andalas University, Padang, Indonesia

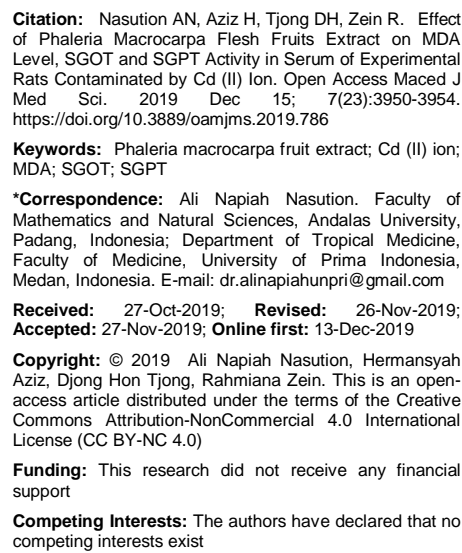
of Phaleria Macrocarpa Flesh Fruits Extract on MDA (in Med Sci. 2019 Dec 15; 7(23):3950-3954 https://doi.org/10.3889/oamjms.2019.786 Keywords: Phaleria macrocarpa fruit extract; $\mathrm{Cd}$ (II) ion; MDA; SGOT; SGPT

*Correspondence: Ali Napiah Nasution. Faculty of Mathematics and Natural Sciences, Andalas University, Padang, Indonesia; Department of Tropical Medicine, Faculty of Medicine, University of Prima Indonesia, Medan, Indonesia. E-mail: dr.alinapiahunpri@gmail.com Received: 27-Oct-2019; Revised: 26-Nov-2019; -2019; Online first: 13-Dec-2019

Copyright: ๑ 2019 Ali Napiah Nasution, Hermansyah aziz, Djong Hon Tjong, Rahmiana Zein. This is an openCommons Attribution-NonCommercial 4.0 Internation License (CC BY-NC 4.0)

Funding: This research did not receive any financia

Competing Interests: The authors have declared that no competing interests exist

\section{Abstract}

BACKGROUND: Cd (II) ion is a heavy metal that has a toxic ability in the human body. P. macrocarpa has been used as anticancer, Diabetes Mellitus and antimicrobe because it consists of flavonoid, steroid, and tannin.

AIM: The purpose of this study was to investigate the effectiveness of $P$. macrocarpa fruits extract as an antidote for the toxicity of $\mathrm{Cd}$ (II) in the liver of experimental rats.

METHODS: The experimental laboratory was done by using 9 female of Wistar rats (Rattus novergicus) that divided into 3 groups with the age between 2.5-3 months and weight between 133-160 grams. The first group was a control given distilled water and a normal diet. The second group was given antidote $5 \mathrm{~mL}$ of $P$. macrocarpa fruit extract $\times \mathrm{BW} / 200 \mathrm{~g}$ dosage for 7 days and induced by $1000 \mathrm{mg} / \mathrm{L}$ of $\mathrm{Cd}$ (II) ion with dosage of $1 \mathrm{~mL} \times \mathrm{BW} / 200 \mathrm{~g}$. The third group was given $1000 \mathrm{mg} / \mathrm{L} \mathrm{Cd}$ (II) ion only of $1 \mathrm{~mL} \times \mathrm{BW} / 200 \mathrm{~g}$. After 5 hours, the blood sample was taken for analysis of MDA, SGOT, and SGPT.

RESULTS: As the result of experimental rats exposed with Cd (II) ion, there are significant decreasing of all the observed parameters including MAD, SGOT and SGPT with percentage $71.5 \%, 72.1 \%$, and $93.6 \%$ respectively.

CONCLUSION: The rats given with the antidote of Phaleria macrocarpa flesh fruit were able to protect the live from damage due to exposure to Cd (II) as seen from the decrease in liver function enzyme parameters namely SGOT and SGPT.

\section{Introduction}

The development of rapid industrialization generated many negative consequences for environmental pollution affecting human health [1]. Many processes in industries including mining, electroplating, dyeing, paper, and crude oil generate wastes that containing heavy metals that toxic to living organisms [2]. Cadmium (Cd), mercury (Hg), Copper $(\mathrm{Cu})$, arsenic $(\mathrm{As})$ and lead $(\mathrm{Pb})$ are dangerous heavy metals that have high toxicity and tendency to accumulate in the food chain even at low concentration. Particularly for $\mathrm{Cd}$ (II) ion and its compound, this heavy metal contributes to a large number of serious health problems including heart disease, cancer and diabetes [3]. Cd (II) ion has been known could cause various health problems such as impaired liver function, lung, bone defects, cancer and hypertension in humans [3]. Exposure to heavy metals such as Cd (II) and As (II) could cause metabolic disorders such as 'itai-itai' emphysema and testicular atrophy [1].

Conventional methods of physical-chemical including electrochemical treatment, ion exchange, precipitation, reverse osmosis, evaporation, and absorption to remove heavy metals are economically high cost and have disadvantages including requires reagent in quantities and generate secondary wastes. Biosorption is an alternative method for removing heavy metals from aqueous solutions and industrial waste [4], [5], [6]. Biosorption process generally low cost and does not pollute the environment [7]. Phaleria macrocarpa is a plant that grows in tropical 
areas primarily in Papua, Indonesia, and is used to address a wide range of health problems such as diabetes and hypertension [8].

The previous study reported that the seed and fruit flesh of $P$. macrocarpa effective for adsorption of Cd (II) with maximum biosorption capacities (Q) were $21.4592 \mathrm{mg} / \mathrm{g}$ and $24.7629 \mathrm{mg} / \mathrm{g}$ respectively [9]. The previous research of Nasution et al., (2015) explained that $P$. macrocarpa contained hydrogen stretching due to inter and intramolecular interaction of alcohol, phenol and carboxylic acid [10]. This functional group will contribute to preventing metal ion from destroying organs.

Based on the Atomic Absorption Spectroscopy (AAS) analysis by Adrian et al., (2015) showed the leaves of Manihot utilissima have a potentially used as an absorbent for $\mathrm{Cd}$ (II) in aqueous solution. In the year, the researchers continue the research about the effect of $\mathrm{Cd}$ (II), mainly in the kidney and liver [11]. The researcher administrates intraperitoneally of cadmium lead to elevated levels of cadmium content in almost organs in rat except in the brain. Administration of cadmium also increases some biochemical parameters and enzymes in serum include malondialdehyde, urea, creatinine, SGOT, and SGPT [10].

The aim of the study was to investigate the effectiveness of $P$. macrocarpa fruits extract as an antidote for the toxicity of $\mathrm{Cd}$ (II) in the liver of experimental rats.

\section{Materials and Method}

\section{Preparation for experimental rats}

Experimental rats used in this study were 9 animals which were divided into 3 groups. The treatment group was as follows group I administration with distilled water and normal diet, group II administration with antidote and Cd (II) $1000 \mathrm{mg} / \mathrm{L}$ and group III administration with Cd (II) 1000 mg/L only.

\section{Analysis of Biosorbent Function Groups with FTIR}

FTIR (Fourier Transform Infrared AA240) analysis of bio sorbents was carried out before and after the absorption of metal ions. The flesh and seeds of the crown of the deity are mashed with mortar added with $\mathrm{KBr}$, then printed into thin discs or pellets. Samples were analyzed by FTIR to determine the functional groups of the flesh of the crown god.

\section{Preparation antidote of $\boldsymbol{P}$. macrocarpa}

The antidote was prepared by weighing 2 grams of the fruit of $P$. macrocarpa and then mashed with distilled water, transferred into a beaker and then add distilled water approximately $120 \mathrm{~mL}$, heated to boiling and then stored in vials tube. The rats induced with the antidote every day for one week with a dose of $5 \mathrm{~mL} \times$ bw/200 $\mathrm{g}$ bw orally.

\section{Histopatology analysis}

After one week, the rats were injected with a solution of $\mathrm{Cd} 1000 \mathrm{mg} / \mathrm{L}$ with a dose of $1 \mathrm{~mL} x$ bw/200 g bw intraperitoneally. After 5 hours, the blood samples and liver were taken for analysis of MDA, SGOT, and SGPT, and histology, respectively. The histopathology analysis was observed using an Olympus microscope. In the third group, the rats only induced using $\mathrm{Cd}$ with a dose of $1 \mathrm{ml} \times \mathrm{bw} / 200 \mathrm{~g} \mathrm{bw}$ intraperitoneally, and after 5 hours, the blood samples were taken for analysis of MDA, SGOT, and SGPT.

\section{Measurement of MDA}

Provided 3 test tubes containing blanks (distilled water), standard MDA solution, serum (sample) $0.5 \mathrm{~mL}$. Add $2.5 \mathrm{ml}$ of $5 \%$ TCA each. Mix using a vortex mixer, centrifuge for 10 minutes at $2000 \mathrm{rpm}$. Each pipette $1.5 \mathrm{~mL}$ filtrate, put into a tube in accordance with the label. Add $1.5 \mathrm{~mL} \mathrm{Na}$ each. Thio Barbituric Acid mix with a vortex mixer, heat it in a water bath for 30 minutes. Cool, read the adsorbent with a spectrophotometer at a wavelength of $530 \mathrm{~nm}$.

\section{Measurement of SGPT Levels in Serum}

Tubes are arranged on a shelf that has been provided, then labeled, starting sample 1 (S1), sample 2 (S2), sample 3 (S3) and so on. Then $100 \mu$ of serum 1 was taken into the $S 1$ tube, $1000 \mu$ of reagent 1 was added (Tris $\mathrm{pH} 7.15100 \mathrm{mmol} / \mathrm{L}$, Lalanine $500 \mathrm{mmol} / \mathrm{L}$, LDH (lactate dehydrogenase $\geq$ $1700 \mathrm{U} / \mathrm{L})$ ), mixed, incubated at room temperature for 5 minutes, $250 \mu$ reagents 2 were added (2-oxoglutaric $15 \mathrm{mmol} / \mathrm{L}$, NADH $0.18 \mathrm{mmol} / \mathrm{L}$, pyridoxal-5phosphate $0.09 \mathrm{mmol} / \mathrm{L}$, buffer $\mathrm{pH} 9.60,7 \mathrm{mmol} / \mathrm{L})$, mixed and read the absorbance after 1,2 and 3 minutes.

\section{Measurement of SGOT Levels in Serum}

The tubes are arranged in a rack that has been provided, then labeled, starting sample 1 (S1), sample 2 (S2), sample 3 (S3) and so on. Then, $100 \mu \mathrm{l}$ of serum 1 input was taken into the $S 1$ tube, $1000 \mu \mathrm{l}$ of reagent was added (Tris $\mathrm{pH} 7.6580 \mathrm{mmol} / \mathrm{L}$, LAspartate $240 \mathrm{mm0l} / \mathrm{L}, \mathrm{MDH}$ (malate dehydrogenase) $\geq 600 \mathrm{U} / \mathrm{L}, \mathrm{LDH} \geq 900 \mathrm{U} / \mathrm{L}$ ) mixed, Incubation at room temperature for 5 minutes, added Reagent 2 (2-oxo 
glutaric $12 \mathrm{mmol} / \mathrm{L}$, NADH $0.18 \mathrm{mmol} / \mathrm{L}$ pyridoxal-5phosphate $0.09 \mathrm{mmol} / \mathrm{L}$, buffer $\mathrm{pH} 9.60 .7 \mathrm{mmol} / \mathrm{L}$ ), as much as $250 \mu \mathrm{l}$, mixed and read the absorbance after 1,2 and 3 minutes.

\section{Result}

\section{Analysis of Adsorbent Function Groups with FTIR}

FTIR (Fourier Transform Infrared) spectroscopy is used to identify functional groups in bio sorbents that might be involved in the process of biosorption of $\mathrm{Cd}(\mathrm{II})$ ions.
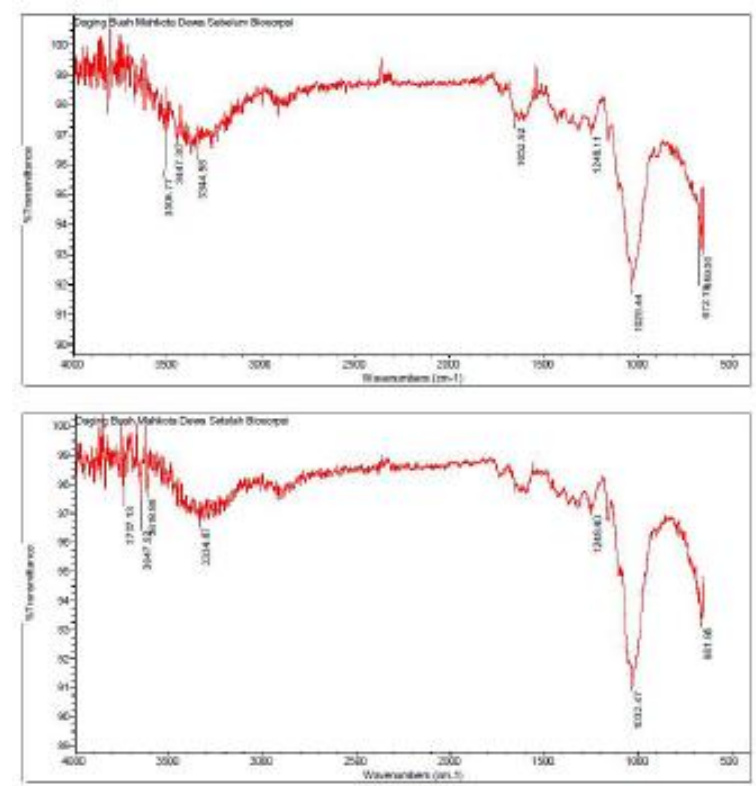

Figure 1: FTIR spectrum of P. macrocarpa; $A$ ) before biosorption; $B$ ) after biosorption

\section{Histological Analysis}

The administration of $\mathrm{Cd}$ (II) ions and the antidote of the crown god flesh powder to $\mathrm{Cd}$ (II) in the liver is shown in Figure 2.

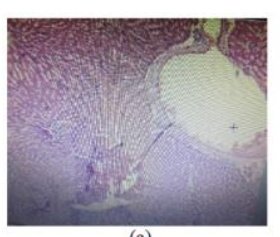

(a)

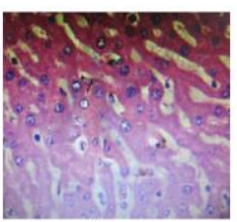

(b)

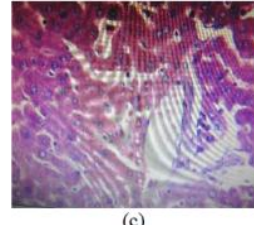

Figure 2: Histopatology of liver on experimental rats; $A$ ) control; $B$ ) $P$. macrocarpa flesh fruit extract with Cd (II) induction; C) Cd (II) ion induction without antidote, magnification $40 \mathrm{X}$

Examination of MDA, SGOT, and SGPT levels in Serum

Blood of rats was taken from each group.
Then centrifuged to get serum. Biochemical results of serum blood are shown in Table 1.

Table 1: The levels of serum biochemical parameters and oxidative stress including MDA, SGOT and SGPT

\begin{tabular}{lcccc}
\hline No & Parameters & Group 1 & Group 2 & Group 3 \\
\hline 1 & MDA (mg/dl) & 3.61 & 4.24 & 14.9 \\
2 & SGOT (U/L) & 111.987 & 66.08 & 236.97 \\
3 & SGPT (U/L) & 25.88 & 12.94 & 203.33 \\
\hline
\end{tabular}

\section{Discussion}

\section{Analysis of Adsorbent Function Groups with FTIR}

Figure 1 indicated the functional group that existed in $P$. macrocarpa flesh fruit. The spectrum presented the hydroxyl group at $3504.77 \mathrm{~cm}^{-1}$ that shifted to $3737.13 \mathrm{~cm}^{-1}$. This phenomenon exhibited the interaction between $P$. macrocarpa flesh fruit with Cd (II) ion. The functional group in the P. macrocarpa flesh fruit formed a stable compound with metal ions so that metal ions could not react further to harm the other organs.

Strong and dense bands at wavelengths of $3500-3200 \mathrm{~cm}^{-1}$ indicate the presence of O-H stretch groups resulting from intra-molecular and intermolecular bonds of hydrogen from alcohols, phenols and carboxylic acids [12]. The band at a wavelength of $3000-2850 \mathrm{~cm}^{-1}$ is estimated to be a C$\mathrm{H}$ stretch group while a carbonyl $\mathrm{C}=\mathrm{O}$ stretch group is shown at a wavelength of $1760-1690 \mathrm{~cm}^{-1}$. Bands at wavelengths from 1500 to $1400 \mathrm{~cm}^{-1}$ indicate C-C stretch or $\mathrm{C}-\mathrm{H}$ groups. $\mathrm{C}-\mathrm{H}$ and $\mathrm{C}-\mathrm{O}$ functional groups are shown at wavelengths of $1320-1000 \mathrm{~cm}^{-1}$ [5]. Figure 1 shows the functional groups found in the flesh of the crown of the gods. The wavenumber at $3344.58 \mathrm{~cm}^{-1}$ is an $\mathrm{OH}$ group which then experiences a shift to $3334.87 \mathrm{~cm}^{-1}$ after adsorption occurs.

\section{Histological Analysis}

Figure 2 presented liver histopathology on experimental rate after $\mathrm{Cd}$ (II) ion and antidote exposure. Figure 2B indicated the surface of the normal liver with light fatty. Meanwhile, Figure 2C indicated that hepatic cells of the liver consisted of lobules with dilatation of Venne centrally. Some of the hepatic cells were cloudy swelling and necrosis.

The liver is the primary target for Cd (II) exposure. About half of $\mathrm{Cd}$ (II) is absorbed systemically very rapidly in the liver, which then results in reduced Cd (II) availability in other organs such as the kidneys and testicles, which are more sensitive to their toxicity. El-Refaiy and Eissa (2012) in their study reported that giving Cd (II) with chronic doses to rats would produce necrosis of hepatocytes, 
fatty, signs of degeneration and infiltration of inflammatory cells. Subchronic exposure to $\mathrm{Cd}$ (II) results in day damage in the form of swelling and necrosis. Necrosis generally occurs in centrilobular and spreads throughout the liver lobules. Histopathological changes in the liver exposed to $\mathrm{Cd}$ (II) may be caused by the formation of free radicals that are very reactive and cause lipid peroxidation to damage the cell membrane [13].

According to Tarasub et al., (2008), Cd (II) metal generally accumulates in hepatocytes and if the concentration of $\mathrm{Cd}$ (II) exceeds the capacity of metallothionein (MT) to bind $\mathrm{Cd}(\mathrm{II})$ it will cause liver damage which is generally characterized by increased SGPT enzymes and SGOT. The increased levels of SGPT and SGOT are due to permeability of hepatocyte membranes damaged by exposure to $\mathrm{Cd}$ (II) so that these enzymes leak into the bloodstream. In addition, GSH plays an important role in the integrity of lipids and proteins in the liver. Consumption of free radical scavenging produced by Cd (II) causes a significant decrease in GSH levels [14]. Tarasub et al., (2008) reported that in mice exposed to $\mathrm{Cd}$ (II), an increase in cytoplasmic hypereosinophilia, cell damage such as pyknosis and necrosis. Damage to liver cells is likely caused by a disruption in thiol hemostasis and ROS production [14].

\section{Examination of MDA, SGOT, and SGPT levels in Serum}

The levels of serum biochemical parameters and oxidative stress including MDA, SGOT, and SGPT are shown in Table 1. After the experimental rats exposed with $\mathrm{Cd}$ (II), there are significant decreasing of all the observed parameters including MDA, SGOT, and SGPT with percentage $71.5 \%$, $72.1 \%$, and $93.6 \%$ respectively, It could be known that the chemical compounds contained in P. macrocarpa fruit extract have the ability to repair the hepatic organ of rats after contaminated by Cd (II). All parts of P. macrocarpa which including pericarp, mesocarp, and seeds contain different kinds of total phenolic and flavonoid compounds. Part of pericarp and mesocarp showed a high content of antioxidant activity using DPPH $(71.97 \%$ and $62.41 \%)$ and free radical scavenging activity (65.68\%) [15]. A similar result reported by Embugishiki et al., (2013), which reported the protective effect of pre-treatment carrot juice against oxidative damage induced by $\mathrm{Cd}$ (II). Pretreatment with carrot juice could prevent lipid peroxidation induced by $\mathrm{Cd}$ (II), prevent decreasing in non-enzymatic antioxidants and reduce the accumulation of cadmium in the liver and kidneys [16].

Poontawee et al., (2016) was reported a protective effect of Cleistocaly xnervosum var paniala fruit extract against oxidative damage due to exposure of Cd (II). Renal oxidative damage occurs after exposure to $\mathrm{Cd}$ (II) characterized by increasing of creatinine, blood urea nitrogen (BUN), reduction in glomerular filtration, renal structural damage was accompanied by in increasing of nitric oxide and MDA [17]. It is estimated that the protective effect was due to the antioxidant and free radical scavenging activity, as well as the interaction of bioactive compounds contained in an extract with enzymatic and nonenzymatic antioxidants. Liver damage induced as a result of $\mathrm{Cd}(\mathrm{II})$ exposure lead to elevated level in liver function parameters including aspartate transaminase (AST), alanine transaminase (ALT), alkaline phosphatase (ALP),lactate dehydrogenase (LDH), gamma-glutamyltransferase (GGT) total serum bilirubin (TB) and it is also accompanied by an increase of thiobarbituric acid reactive substances (TBARS) [18].

Cd (II) exposure in experimental rats will lead to changes level of serum biochemical parameters such as MDA, SGPT, and SGOT. Pre-treatment with $P$. macrocarpa flesh fruit antidote could significantly reduce the elevated levels of serum biochemical parameters. Pre-treatment with $P$. macrocarpa flesh fruit antidote could reduce the hepatotoxicity effect induced by $\mathrm{Cd}$ (II) that might be due to the high content of antioxidant and free radical scavenging activity. On the other hand, the lower of MDA in this research show the effect of the extract which prevents organ damage caused by ROS and Oxidative stress.

This study concluded that the rats given with the antidote of Phaleria macrocarpa fruit flesh were able to protect the liver from damage due to exposure to $\mathrm{Cd}(\mathrm{II})$ as seen from the decrease in liver function enzyme parameters namely SGOT and SGPT.

\section{References}

1. Kamsonlian S, Balomajumder C, Chand S, Suresh S.

Biosorption of $\mathrm{Cd}$ (II) and As (III) ions from aqueous solution by tea waste biomass. African Journal of Environmental Science and Technology. 2011; 5(1):1-7.

2. El-Sayed GO, Dessouki HA, Ibrahim SS. Biosorption of Ni (II) and $\mathrm{Cd}$ (II) ions from aqueous solutions onto rice straw. Chemical Sciences Journal. 2010; 2010(9):1-1. https://doi.org/10.4172/21503494.1000007

3. Chen JP, Lin YS. Sol-gel-immobilized recombinant E. coli for biosorption of $\mathrm{Cd} 2+$. Journal of the Chinese Institute of Chemical Engineers. 2007; 38(3-4):235-43.

https://doi.org/10.1016/j.jcice.2007.03.005

4. Zein R, Suhaili R, Earnestly F, Munaf E. Removal of Pb (II), Cd (II) and Co (II) from aqueous solution using Garcinia mangostana L. fruit shell. Journal of hazardous materials. 2010; 181(1-3):52-6. https://doi.org/10.1016/i.jhazmat.2010.04.076 PMid:20627410

5. Zein R, Hidayat DA, Elfia M, Nazaruddin N, Munaf E. Journal of Water Supply: Research and Technology-AQUA. 2014; 63(7):553559. https://doi.org/10.2166/aqua.2014.120

6. Zein R. AIP Conference Proceedings, 2023(020099), 2018:1.

7. Oyebamiji BJ, Overah L, Babarinde A, Oninla VO, Olatunde A. Kinetic, equilibrium and thermodynamic studies on the biosorption of $\mathrm{Cd}$ (II) from aqueous solutions by the leaf biomass of Calotropis 
procera-Sodom apple. J. Apple. Sci. Environ. Manage. 2011; 15(4):607-615. https://doi.org/10.4314/jasem.v15i1.65681

8. Diantini A, Subarnas A, Supriyatna LJ, Abdulah R, Achmad TH, Faried A, et al. Cytotoxicity of fevicordin-A from Phaleria macrocarpa (Scheff.) Boerl. on P388, HeLa, Caski, TE-2, TE-8 and Prepuce's Fibroblast cells. J Med Res. 2012; 1:1-5.

9. Adrian et al. Research Journal of Pharmaceutical, Biological and Chemical Sciences. 2016; 7(5):1228.

10. Nasution AN, Amrina Y, Zein R, Aziz H, Munaf E. Biosorption characteristics of $\mathrm{Cd}$ (II) ions using herbal plant of mahkota dewa (Phaleria macrocarpa). Journal of Chemical and Pharmaceutical Research. 2015; 7(7):189-96.

11. Adrian, Fachrial E, Almahdy A, Syaifullah S, Munaf E, Zein R. Biosorption of cadmium (II) ions from aqueous solution by cassava (Manihot utilissima) leaves. Journal of Chemical and Pharmaceutical Research. 2015; 7(9S):1.

12. Huang $\mathrm{K}$, Xiu $\mathrm{Y}$, Zhu H. Selective removal of $\mathrm{Cr}(\mathrm{VI})$ from aqueous solution by adsorption on mangosteen peel.

Environmental Science and Pollution Research. 2013; 20(9):5930-

8. https://doi.org/10.1007/s11356-013-1497-0 PMid:23397175

13. El-Refaiy Al, Eissa FI. Histopathology and cytotoxicity as biomarkers in treated rats with cadmium and some therapeutic agents. Saudi journal of biological sciences. 2013; 20(3):265-80. https://doi.org/10.1016/j.sjbs.2013.02.004 PMid:23961244 PMCid:PMC3730709

14. Unit A. Effects of curcumin on cadmium-induced hepatotoxicity in rats. Thai J Toxicology. 2008; 23(2):100-7.

15. Hendra R, Ahmad S, Oskoueian E, Sukari A, Shukor MY. Antioxidant, anti-inflammatory and cytotoxicity of Phaleria macrocarpa (Boerl.) Scheff fruit. BMC complementary and alternative medicine. $2011 ; 11(1): 110$.

https://doi.org/10.1186/1472-6882-11-110 PMid:22070850 PMCid:PMC3354343

16. Embugushiki RE, Mafulul SG, Okoye ZS. Protective effect of carrot juice pre treatment on cadmium induced cytotoxic damage to some rat tissues. IOSR Journal of Pharmacy and Biological Sciences. 2013; 7(6):55-62. https://doi.org/10.9790/3008-0765562

17. Poontawee W, Natakankitkul S, Wongmekiat. Molecules. 2016; 21(133). https://doi.org/10.3390/molecules21020133 PMid:26805807 PMCid:PMC6273200

18. Renugadevi J, Prabu SM. Experimental and toxicologic pathology: official journal of the Gesellschaft fur Toxikologische Pathologie. 2009; 62(2):171. 